\title{
PPM PELATIHAN PEMANFAATAN KOMPUTER KARANG TARUNA DESA PENGALANGAN KECAMATAN MENGANTI KABUPATEN GRESIK
}

\author{
Suryo Atmojo ${ }^{1}$, Suzana Dewi ${ }^{2}$, Nurwahyudi Widhiyanta ${ }^{3}$, Ruli Utami ${ }^{4}$ \\ ${ }^{123}$ Universitas Wijaya Putra, ${ }^{2}$ Institut Teknologi Adhi Tama Surabaya \\ ${ }^{1}$ suryoatmojo@uwp.ac.id, ${ }^{2}$ suzanadewi@uwp.ac.id, ${ }^{3}$ nurwahyudiwidhiyanta@uwp.ac.id, \\ ${ }^{4}$ ruli.utami@itats.ac.id
}

\begin{abstract}
Abstrak
Program Pengabdian Pada Masyarakat (PPM) yang dilakukan bertujuan untuk melatih remaja karang taruna untuk mengembangkan skill pemanfaatan komputer. Berdasarkan informasi hasil wawancara yang diperoleh, masalah utama yang dihadapi remaja karang taruna di desa pengalangan adalah kurangnya pemanfaatan komputer secara positif sebagai sarana berkreasi serta pemanfaatan komputer sebagai alat untuk membantu mempercepat, mempermudah pekerjaan, serta mendapatkan informasi. Dari jumlah 40 anggota karang taruna hanya 9 orang yang dapat menggunakan komputer sebagai sarana mempermudah kerja, 12 orang sebagai sarana komunikasi, 35 orang sebagai alat hiburan, 8 orang sebagai alat Pendidikan, 10 orang memanfaatkan komputer sebagai sarana pencari informasi, 7 orang sebagai sarana usaha dan 2 orang memanfaatkan komputer sebagai sarana kontrol. Selanjutnya dilaksanakan pelatihan untuk memanfaatkan komputer secara positif pada bulan september. Jumlah peserta sebanyak 40 orang. Materi yang disampaikan pada saat pelatihan ialah 1) Pengertian dan dasar teori penggunaan perangkat komputer, 2) Pelatihan aplikasi pengolah grafis, 3) Pelatihan cara memperoleh informasi seputar Pendidikan, lowongan kerja, serta perdagangan, 4) pelatihan membuat media promosi wisata desa, 5) pelatihan pemanfaatan market place. Setelah pelatihan, hasil yang didapatkan ialah 1) anggota karang taruna sudah dapat membuat desain media promosi wisata desa 2) anggota karang taruna mempunyai akun usaha pada market place.
\end{abstract}

Kata Kunci : komputer, pengabdian, teknologi, desa

\section{PENDAHULUAN}

\subsection{Analisis Situasi}

Mitra yang menjadi mitra Program Pemberdayaan Masyarakat (PPM) ini adalah Karang taruna Desa Pengalangan Dimana letak desa Pengalangan lebih tepatnya letak desa ini berbatasan dengan kota Surabaya di sebelah utara dan timur, berbatasan dengan desa Setro di sebelah selatan, dan berbatasan dengan desa Randupadangan di sebelah barat. Berdasarkan informasi hasil wawancara yang diperoleh dari perangkat desa sekaligus koordinator karang taruna desa pengalangan bahwa masalah utama yang dihadapi remaja karang taruna adalah yaitu kurangnya kesadaran akan tanggung jawab sosial dalam antisipasi, mencegah dan menangkal berbagai permasalahan sosial; kesulitan dalam mengumpulkan anggota karang taruna serta ketrampilan dalam pemanfaatan teknologi informasi seperti penguasaan hardware komputer dan pemahaman software. Persentase anggota yang menguasai hardware hanya sekitar $20 \%$ dari jumlah keseluruhan anggota Karang Taruna, sedangkan 
untuk penguasaan software kurang lebih $30 \%$ dari total anggota.

Kondisi nyata remaja karang taruna ini adalah banyak diantara mereka yang tidak memiliki PC atau laptop. Sebenarnya daya dukung transfer informasi dan teknologi pada karang taruna cukup memadai. Hal ini terlihat pada ketersediaan beberapa komputer di balai desa yang bisa digunakan untuk berlatih mengoperasikan software seperti Ms Office. Sementara itu, selama ini baik perorangan maupun institusi belum ada yang memberikan pelatihan tentang pemahaman perangkat keras komputer serta penguasaan perangkat lunak kepada remaja karang taruna Desa Pengalangan, Kecamatan Menganti, Kabupaten Gresik. Berkaitan dengan fakta-fakta di atas, maka perlu kiranya para remaja diberikan pelatihan tentang memahami perangkat keras dan memahami perangkat lunak seperti pengoperasian Ms Office. Maka untuk itulah, kami tertarik untuk mengadakan pelatihan penguasaan perangkat keras dan perangkat lunak bagi remaja karang taruna. Tujuan dari kegiatan pengabdian kepada masyarakat ini adalah untuk membantu remaja karang taruna untuk mengembangkan skill pemanfaatan teknologi informasi dalam mengoperasikan komputer khususnya aplikasi seperti one note, Camtasia dan program Ms Office. Implikasi yang diharapkan dari pengabdian kepada masyarakat ini adalah para remaja karang taruna menjadi mahir memanfaatkan teknologi informasi dalam menyusun program kerja kegiatan karang taruna desa.

\subsection{Profil Mitra}

Adapun profil dari mitra Karang Taruna Desa Pengalangan khusus nya berdasarkan keaktifan keanggotaan Karang Taruna yaitu dari dusun bongso wetan dan dusun bongso kulon rata rata memiliki anggota 15 orang sehingga total dari kedua desa tersebut kurang lebih 30 orang. Demografi umur yang tersebar dari keanggotaan tersebut yaitu berkisar antara 17 tahun hingga usia 30 tahun. Dari 30 anggota tersebut, anggota yang memiliki pemahaman tentang hardware komputer kurang lebih sekitar 6 orang dan untuk yang memiliki pemahaman tentang software office sekitar 10 orang. Dari keseluruhan anggota, rata rata hampir semua sudah dapat menggunakan media youtube sebatas sebagai pengguna, namun belum ada yang dapat memanfaatan media youtube sebagai konten creator.

\section{Permasalahan Mitra}

Program kerja karang taruna ialah suatu kegiatan yang akan dilakukan dalam jangka waktu tertentu dan disusun secara terperinci (Hertanti, 2018). Di dalam program kerja karang taruna terkandung unsur-unsur berikut:

1. Tingkat persoalan

2. Tujuan

3. Strategi

4. Program kegiatan

5. Hasil yang akan dicapai

6. Jadwal kegiatan

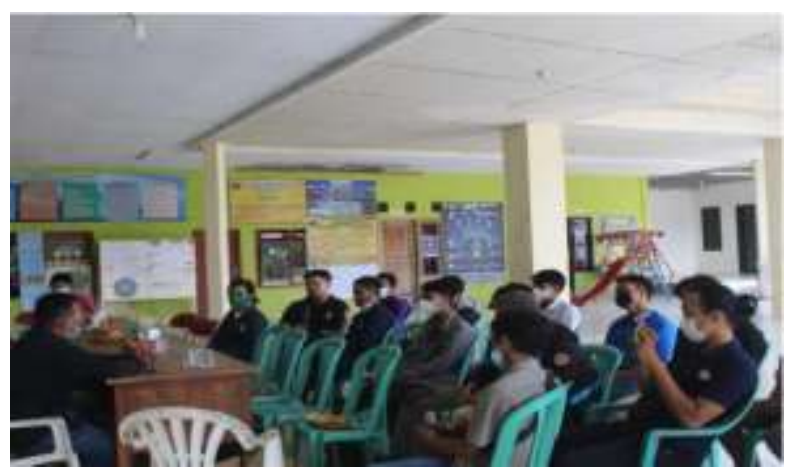

Berdasarkan uraian kondisi mitra sebagaimana disampaikan pada Analisa situasi di atas, maka permasalahan mendasar yang dihadapi oleh karang taruna desa pengalangan dalam pengembangan organisasi menggunakan teknologi informasi dapat dikalsifikasikan menjadi, penguasaan hardware, penguasaan software, serta pengembangan brainware

\begin{tabular}{|l|l|l|l|}
\hline No & $\begin{array}{l}\text { Aspek } \\
\text { permasalahan }\end{array}$ & Permasalahan & Solusi \\
\hline 1 & Penguasaan & Kurangnya & Memberikan \\
\hline
\end{tabular}




\begin{tabular}{|c|c|c|c|}
\hline & Hardware & $\begin{array}{l}\text { pemahaman } \\
\text { mendasar } \\
\text { tentang } \\
\text { hardware atau } \\
\text { perangkat } \\
\text { keras seputar } \\
\text { teknologi } \\
\text { seperti 1) } \\
\text { Pemahaman } \\
\text { perangkat } \\
\text { laptop; 2) } \\
\text { Pemahaman } \\
\text { part part } \\
\text { komputer }\end{array}$ & $\begin{array}{l}\text { pelatihan } \\
\text { mengenai apa } \\
\text { saja } \\
\text { komponen } \\
\text { pendukung } \\
\text { komputer dan } \\
\text { laptop, serta } \\
\text { bagaimana } \\
\text { melakukan } \\
\text { installasi } \\
\text { sistem } \\
\text { operasi dan } \\
\text { mengatasi } \\
\text { masalah pada } \\
\text { aperangkat } \\
\text { keras }\end{array}$ \\
\hline 2 & $\begin{array}{l}\text { Penguasaan } \\
\text { Software }\end{array}$ & $\begin{array}{l}\text { Kurangnya } \\
\text { pemahaman } \\
\text { ketrampilan } \\
\text { penguasaan } \\
\text { software } \\
\text { pendukung } \\
\text { organisasi } \\
\text { seperti : } \\
\text { 1) Office } \\
\text { word; 2) } \\
\text { Office excel; } \\
\text { 3) Office } \\
\text { power point; } \\
\text { 4) Aplikasi } \\
\text { desain } \\
\text { (photoshop), } \\
\text { Kurangnya } \\
\text { pemahaman } \\
\text { tentang } \\
\text { bagaimana } \\
\text { installasi } \\
\text { sistem operasi } \\
\text { dan mengatasi } \\
\text { masalah pada } \\
\text { penggunaan } \\
\text { komputer }\end{array}$ & $\begin{array}{l}\text { Mengadakan } \\
\text { pelatihan } \\
\text { ketrampilan } \\
\text { menggunaka } \\
\text { n aplikasi } \\
\text { office }\end{array}$ \\
\hline 3 & $\begin{array}{l}\text { Pengembanga } \\
\mathrm{n} \text { Brainware }\end{array}$ & $\begin{array}{l}\text { Kurangnya } \\
\text { kreatifitas } \\
\text { pemanfaatan } \\
\text { teknologi, } \\
\text { sebatas hanya } \\
\text { untuk bermain } \\
\text { game }\end{array}$ & $\begin{array}{l}\text { Memberikan } \\
\text { pelatihan } \\
\text { bagaimana } \\
\text { memanfaatka } \\
\mathrm{n} \text { media } \\
\text { digital / } \\
\text { teknologi } \\
\text { informasi } \\
\text { sebagai } \\
\text { sumber } \\
\end{array}$ \\
\hline
\end{tabular}

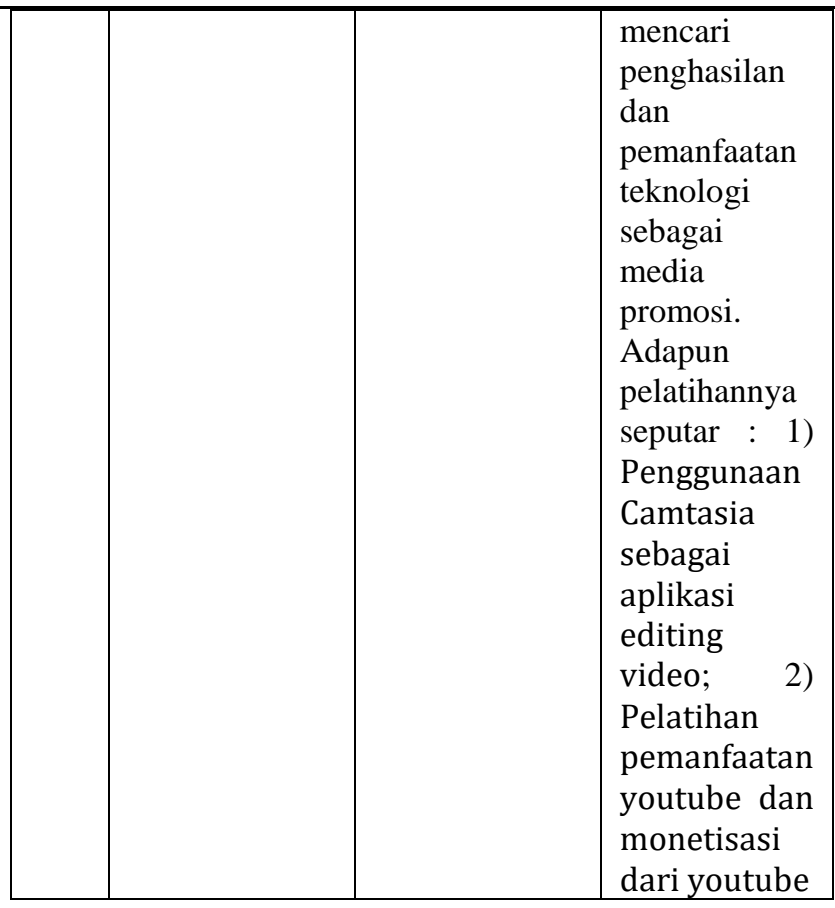

\section{SOLUSI DAN TARGET LUARAN}

Solusi yang ditawarkan dalam program pengabdian masyarakat ini adalah pelatihan pemanfaatan komputer secara positif bagi karang taruna desa Pengalangan Kecamatan Menganti Kabupaten Gresik. Berdasarkan data survey, pemanfaatan komputer dan media digital pada Karangtaruna desa Pengalangan masih sangat minim. Begitu pula dengan pemahaman perangkat keras dan pemahaman penggunaan perangkat lunak untuk mendukung kegiatan karang taruna juga masih minim. Pelathan ini diharapkan dapat meningkatkan penggunaan komputer, aplikasi pendukung administarsi karang taruna desa serta penguasaan media digital. Pelatihan ini diharapkan menjadi stimulus untuk karang taruna agar memajukan desa di era pandemi serta mengikuti perkembangan era revolusi industri 4.0.

\begin{tabular}{|c|c|c|}
\hline Permasalahan & Solusi & Target Luaran \\
\hline $\begin{array}{l}\text { Kurangnya } \\
\text { pemahaman } \\
\text { mendasar } \\
\text { tentang } \\
\text { hardware atau } \\
\text { perangkat keras } \\
\text { seputar }\end{array}$ & $\begin{array}{l}\text { Memberikan } \\
\text { pelatihan } \\
\text { mengenai apa } \\
\text { saja } \\
\text { komponen } \\
\text { pendukung } \\
\text { komputer dan }\end{array}$ & $\begin{array}{l}\text { 1) Setiap anggota } \\
\text { karang taruna } \\
\text { mampu } \\
\text { mengidentifika } \\
\text { si, mengenali } \\
\text { dan } \\
\text { memahami }\end{array}$ \\
\hline
\end{tabular}




\begin{tabular}{|c|c|c|}
\hline $\begin{array}{l}\text { teknologi } \\
\text { seperti } \\
\text { 1) Pemahaman } \\
\text { perangkat } \\
\text { laptop; 2) } \\
\text { Pemahaman } \\
\text { part part } \\
\text { komputer }\end{array}$ & $\begin{array}{l}\text { laptop, serta } \\
\text { bagaimana } \\
\text { melakukan } \\
\text { installasi } \\
\text { sistem operasi } \\
\text { dan mengatasi } \\
\text { masalah pada } \\
\text { aperangkat } \\
\text { keras }\end{array}$ & $\begin{array}{ll}\text { perangkat } \\
\text { keras laptop } \\
\text { dan komputer } \\
\text { 2) } & \text { Anggota karang } \\
\text { taruna dapat } \\
\text { melakukan } \\
\text { instalasi sistem } \\
\text { operasi } \\
\text { 3) Anggota karang } \\
\text { taruna dapat } \\
\text { melakukan } \\
\text { backup data } \\
\text { pada storage } \\
\text { cloud }\end{array}$ \\
\hline $\begin{array}{l}\text { Kurangnya } \\
\text { pemahaman } \\
\text { ketrampilan } \\
\text { penguasaan } \\
\text { software } \\
\text { pendukung } \\
\text { organisasi } \\
\text { seperti : } \\
\text { 1) Office word } \\
\text { 2) Office } \\
\text { excel } \\
\text { 3) Office } \\
\text { power point } \\
\text { 4) Aplikasi } \\
\quad \text { desain } \\
\text { (photoshop) } \\
\text { Kurangnya } \\
\text { pemahaman } \\
\text { tentang } \\
\text { bagaimana } \\
\text { installasi sistem } \\
\text { operasi dan } \\
\text { mengatasi } \\
\text { masalah pada } \\
\text { penggunaan } \\
\text { komputer }\end{array}$ & $\begin{array}{l}\text { Mengadakan } \\
\text { pelatihan } \\
\text { ketrampilan } \\
\text { menggunakan } \\
\text { aplikasi office }\end{array}$ & $\begin{array}{lr}\text { Setiap } & \text { anggota } \\
\text { karang } & \text { taruna } \\
\text { mampu } & \\
1 \text { 1) Menguasai } \\
\text { aplikasi } \\
\text { dalam membuat } \\
\text { surat dan program } \\
\text { kerja kartar; } \\
\text { 2) menguasai } \\
\text { aplikasi office excel } \\
\text { penggunaan rumus } \\
\text { formula; } \\
\text { 3) menguasai } \\
\text { power r point } \\
\text { membuat presntasi } \\
\text { interaktif dan } \\
\text { menarik din }\end{array}$ \\
\hline $\begin{array}{l}\text { Kurangnya } \\
\text { kreatifitas } \\
\text { pemanfaatan } \\
\text { teknologi, } \\
\text { sebatas hanya } \\
\text { untuk bermain } \\
\text { game }\end{array}$ & $\begin{array}{l}\text { Memberikan } \\
\text { pelatihan } \\
\text { bagaimana } \\
\text { memanfaatka } \\
\mathrm{n} \quad \text { media } \\
\text { digital / } \\
\text { teknologi } \\
\text { informasi } \\
\text { sebaagai } \\
\text { sumber } \\
\text { mencari }\end{array}$ & $\begin{array}{l}\text { 1)Setiap aanggota } \\
\text { karang taruna } \\
\text { memiliki channel } \\
\text { youtube; } \\
\text { 2)Membuat video } \\
\text { kreatif seputar } \\
\text { desa pengalangan } \\
\text { terupload di } \\
\text { youtube; }\end{array}$ \\
\hline
\end{tabular}

\begin{tabular}{|l|l|l|}
\hline & penghasilan & \\
dan & pemanfaatan & \\
teknologi & sebagai media & promosi. \\
Adapun & \\
pelatihannya & \\
seputar : & \\
1) \\
Penggunaan & \\
Camtasia & \\
sebagai & aplikasi \\
editing video; & 2) Pelatihan \\
pemanfaatan & youtube dan \\
monetisasi & dari youtube \\
\hline
\end{tabular}

\section{METODE}

Adapun langkah-langkah pelaksanaan program pengabdian masyarakat ini adalah sebagai berikut:

1. Koordinasi dengan mitra terkait jadwal dan tempat pelaksanaan pelatihan. Sasaran program pelatihan adalah anggota karang taruna. Oleh karena itu, diperlukan koordinasi intens untuk menentukan jadwal pelatihan yang tidak mengganggu aktivitas. Adapun tempat pelaksanaan akan disediakan oleh mitra adalah balai desa pengalangan.

2. Persiapan pelatihan.

Persiapan mencakup persiapan bahan materi bagi karang taruna, pembuatan modul pengenalan hardware dan software, pembuatan instrument penilaian berupa kuisioner yang akan dibagikan sebelum dan sesudah pelatihan.

3. Pelaksanaan pelatihan.

Pelatihan dilaksanakan dengan pendekatan partisipatif dimana tim pengusul akan mengajar langsung para anggota karang taruna selama beberapa pertemuan. Setiap pertemuan mentargetkan capaian bagi para anggota karang taruna hingga pada pertemuan terakhir anggota karang taruna telah dapat membuat konten media digital dan konten media promosi desa.

Teknologi Informasi dan Komunikasi 
4. Evaluasi Proses Pelatihan

Hasil kuisioner diolah dan dianalisa untuk diketahui hasil akhir dari pelatihan apakah sesuai dengan yang diharapkan. Evaluasi ini berguna untuk pelatihan-pelatihan selanjutnya di program pengabdian yang lain, dan berguna juga untuk memberi tambahan informasi yang mungkin belum tersampaikan selama pelatihan kepada mitra.

5. Pemberian modul untuk anggota karang taruna. Tim pengusul akan memberikan modul

Pemanfaatan komputer dan media digital anggota karang taruna.

6. Pembuatan jurnal ilmiah dan laporan akhir. Sebagai luaran wajib program pengabdian ini maka kami akan membuat jurnal ilmiah dan laporan akhir ketika semua program telah selesai dilaksanakan.

Setelah pelatihan ini selesai diharapkan anggota karang taruna mendapat manfaat berupa ilmu baru yaitu memanfaatkan komputer sebagai alat bantu administrasi karang taruna desa serta membuat konten digital promosi desa.

\section{HASIL DAN PEMBAHASAN}

Sesuai alternative solusi yang telah disepakati dengan mitra, maka telah dilaksanakan pelatihan pembuatan media digital pembelajaran. Dari rencana lima materi utama pelatihan yang sudah dirumuskan, hingga saat ini telah terlaksana secara keseluruhan. Adapun daftar pelatihan yang telah terlaksana, dapat di lihat pada tabel 1 berikut.

\begin{tabular}{|l|l|l|}
\hline No & Tanggal & Detail \\
\hline 1 & $11 / 09 / 21$ & Pembukaan \\
\hline 2 & $12 / 09 / 21$ & $\begin{array}{l}\text { Diskusi IT, pengenalan } \\
\text { hardware (perangkat keras) }\end{array}$ \\
\hline 3 & $13 / 09 / 21$ & $\begin{array}{l}\text { Diskusi IT, pengenalan Sistem } \\
\text { Operasi dan perangkat lunak }\end{array}$ \\
\hline 4 & $14 / 09 / 21$ & $\begin{array}{l}\text { Pelatihan pemanfaatan } \\
\text { aplikasi administrasi }\end{array}$ \\
\hline 5 & $15 / 09 / 21$ & $\begin{array}{l}\text { Pelatihan pembuatan video } \\
\text { promosi desa }\end{array}$ \\
\hline 6 & $16 / 09 / 21$ & $\begin{array}{l}\text { Pemaanfaatan media digital } \\
\text { dan social media sebagai }\end{array}$ \\
\hline
\end{tabular}

\begin{tabular}{|l|l|l|}
\hline & & media promosi desa \\
\hline 7 & $17 / 09 / 21$ & $\begin{array}{l}\text { Diskusi penggunaan } \mathrm{e}- \\
\text { commerce }\end{array}$ \\
\hline 8 & $18 / 09 / 21$ & Penutupan \\
\hline
\end{tabular}

\section{Pembukaan}

Pada kegiatan ini dilakukan pembukaan acara yang dihadiri oleh ketua karang taruna dan beberapa pengurus desa.

\section{Diskusi IT pengenalan hardware}

Pada kegiatan kali ini dijabarkan tentang bagian bagian dari komputer seperti 1) processor; 2) motherboard; 3) RAM; 4) Storage; 5) VGA

Pengenalan Sistem Operasi dan Software Pada kegiatan kali ini diperkenalkan beberapa sistem operasi dan aplikasi seperti adobe family, dan camtasia

\section{Pelatihan Pemanfaatan aplikasi administrasi}

Pada kegiatan kali ini diperkenalkan microsoft apps seperti, word, excel dan power point

\section{Pelatihan pembuatan video promosi desa}

Pemanfaatan aplikasi komputer dalam pembelajaran digital dapat menggunakan beberapa platform yang tersedia seperti youtube, Camtasia, videoscribe

\section{Diskusi Penggunaan E-Commerce}

Pada pertemuan kali ini dilakukan diskusi Bersama membahas seputar pemanfaatan e-commerce untuk anggota karang taruna dan masyarakat umum desa

Proses pelatihan pada dapat dilihat pada gambar dibawah ini :

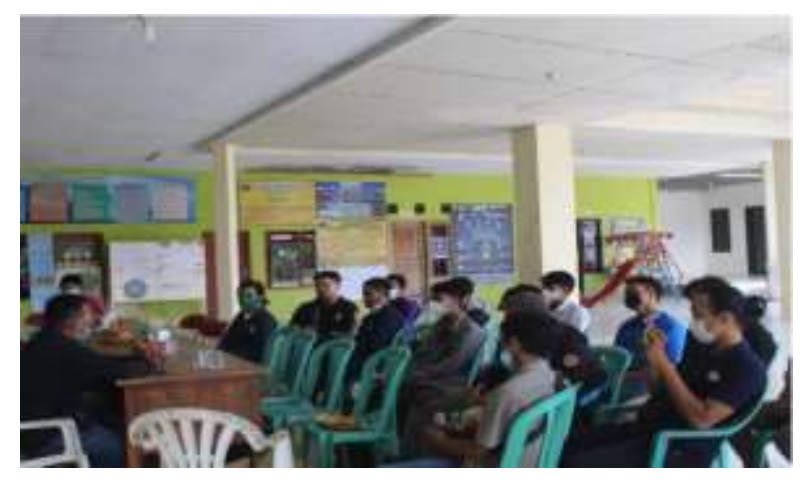


Gambar 1. a) Pembukaan Pelatihan

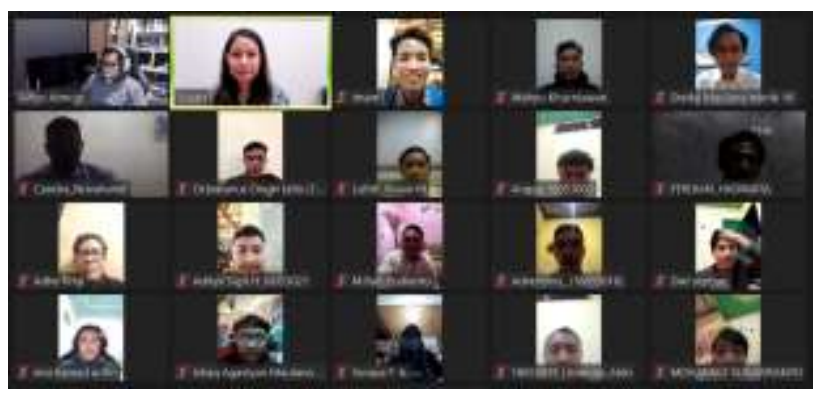

Gambar 1. b) Pelatihan pemanfaatan media digital

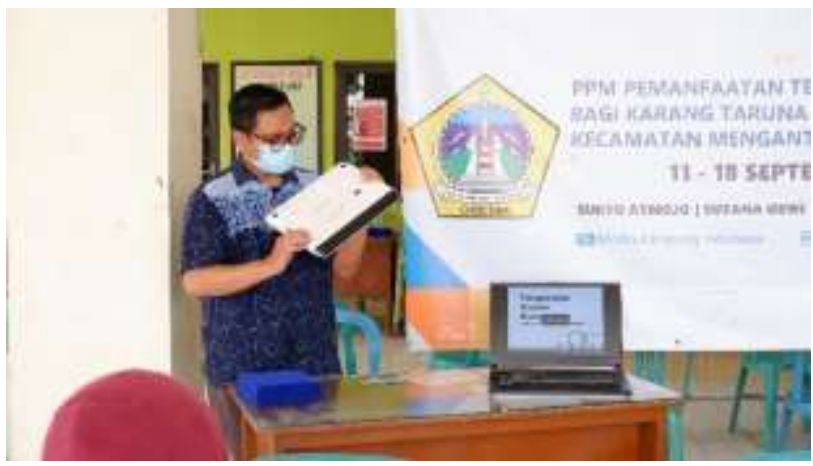

Gambar 1. c) pelatihan pengenalan perangkat keras

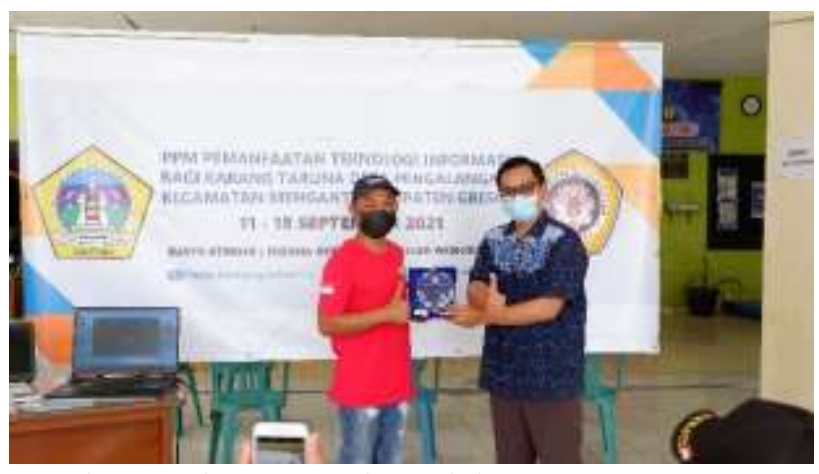

Gambar 1.d) penyerahan plakat

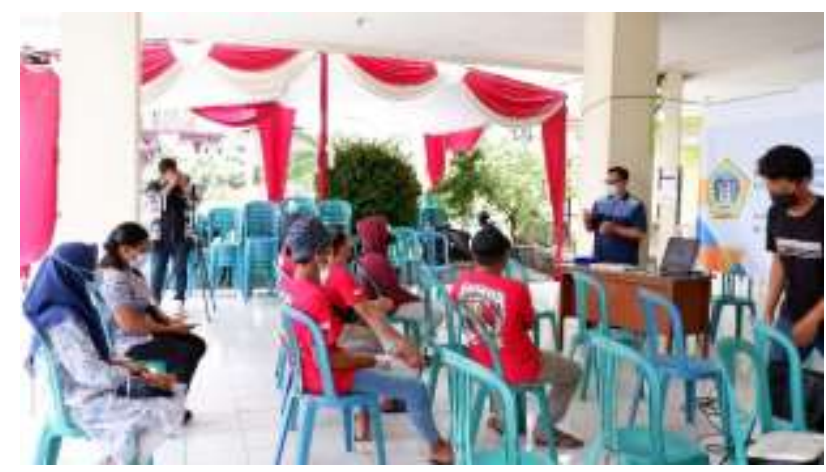

Gambar 1. e) Pelatihan perangkat lunak

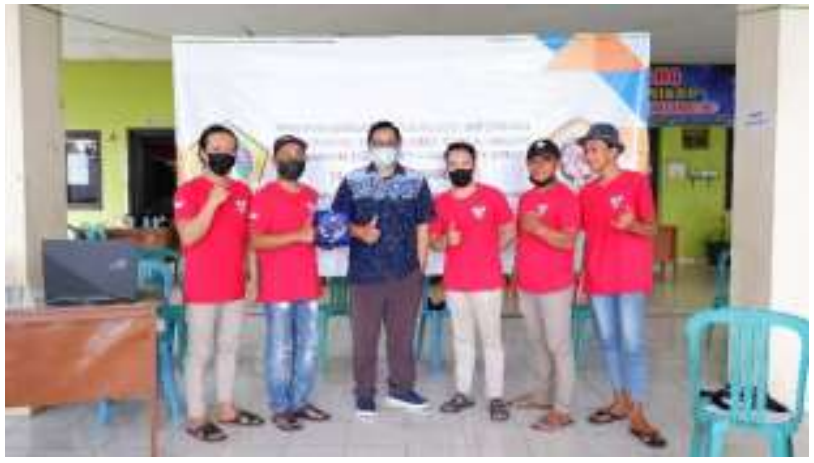

Gambar 1. f) Penutupan Pelatihan

Adapun tindak lanjut dari pelatihan secara offline adalah diskusi materi melalaui kanal youtube dimana materi dapat di akses di https://www.youtube.com/watch?v=rkbWGooiK1A \&list=PLnsAlrnxPLjdYUW62QFVtcom1uzfvmix1

\section{KESIMPULAN}

Kesimpulan berisi rangkuman hasil kegiatan pengabdian kepada masyarakat dan implikasi dari kegiatan yang dilaksanakan.

Adapun kesimpulan yang dapat ditarik dari kegiatan ini adalah sebagi berikut :

1. Penggunaan teknologi informasi sangat menunjang dalam pembuatan media promosi desa untuk menunjang kegiatan karang taruna desa khususnya pada era pendemi covid dalam pengembangan kegiatan dan kamamouan anggota karang taruna desa.

2. Penggunaan serta pemanfaatan komputer dapat menunjang penyusunan program

Teknologi Informasi dan Komunikasi 28 
kerja karang taruna dan juga sangat membantu anggota karang taruna dalam mengembangkan kreatifitas dalam memahami penggunaan komputer secara positif.

3. Literasi TIK bagi warga desa khususnya karang taruna desa perlu ditingkatkan agar mahir dan lebih Kreativitas lagi bagi pengembangan serta pemanfaatan koputer.

\section{REFERENSI}

agung, o. (2019). pemberdayaan pemuda karang taruna melalui program remaja peduli lingkungan desa wisata kebontunggul. penamas adi buana.

ashary, 1. (2016). optimalisasi pemberdayaan karang taruna dalam pengembangan desa silomukti kabupaten situbondo. dinamika global: rebranding keunggulan kompetitif berbasis kearifan lokal. fibrianti, o., momo, a. h., \& nerlin, n. (2020). pelaksanaan fungsi organisasi karang taruna di desa tapuhaka kecamatan kabaena timur. selami https://doi.org/10.36709/selami.v13i1.13619

hamid, r. s., \& ikbal, m. (2017). pemberdayaan pemuda melalui program remaja pintar berbasis ekonomi kreatif desa lera kecamatan wotu kabupaten luwu timur. resona: jurnal ilmiah pengabdian masyarakat. https://doi.org/10.35906/jipm01.v1i1.250

hertanti, s. (2018). pelaksanaan program karang taruna dalam upaya meningkatkan pembangunan di desa cintaratu kecamatan parigi kabupaten pangandaran. jurnal moderat.

widodo, a. (2017). program pemberdayaan 'sedekah pohon pisang': peran karang taruna di desa gandri, lampung selatan. jurnal pemberdayaan masyarakat: media pemikiran dan dakwah pembangunan.

https://doi.org/10.14421/jpm.2017.011-01 